\title{
Ruminal behaviour of structural carbohydrates, non-structural carbohydrates and crude protein from concentrate ingredients in dairy cows
}

\author{
S. TAMMINGA ${ }^{2}$, A. M. VAN VUUREN 1 , C. J. VAN DER KOELEN 1, R. S. \\ KETELAAR $^{3}$ \& P. L. VAN DER TOGT ${ }^{2}$ \\ 1 Research Institute for Livestock Feeding and Nutrition, P.O. Box 160, NL 6200 AD \\ Lelystad, Netherlands \\ 2 Present address: Department of Animal Nutrition, Wageningen Agricultural University, \\ Haagsteeg 4, NL 6708 PM Wageningen, Netherlands \\ 3 Present address: Experimental Farm 'Groot Kantwijk', UT Delfia BV, Bergseweg 28, \\ NL 3633 AK Vreelant, Netherlands
}

Received 23 November 1989; accepted 14 March 1990

\begin{abstract}
Ruminal degradation characteristics of Neutral Detergent Fibre (NDF), starch and crude protein (CP) in concentrate ingredients were determined in dairy cows by means of nylon bag incubations. Measured characteristics were soluble fraction (starch, CP), undegradable fraction (NDF, CP), lag time (NDF) and rate of degradation of the insoluble but degradable fraction (NDF, starch, CP). All measured characteristics showed large variation. Based on measured and partly estimated characteristics ratio's were calculated between total rumen available CP and carbohydrates, between soluble CP and soluble carbohydrates and between insoluble rumen available $\mathrm{CP}$ and insoluble rumen available carbohydrates. Ratio's varied largely between feedstuffs and between soluble and insoluble fractions. It was concluded that such ratio's can be used to optimize the composition of concentrates with regard to rumen fermentation.
\end{abstract}

Keywords: rumen fermentation, protein, carbohydrates, starch, cell walls

\section{Introduction}

For dairy cows, carbohydrates are important precursors of energy yielding nutrients, either as structural polysaccharides like pectins, cellulose or hemicellulose, or as storage polysaccharides like starches and fructosans or as oligo-, di- and monosaccharides. At the same time they are the main energy yielding substrates for the microbial population in the rumen. Finally they may play an important role in stabilizing or destabilizing rumen fermentation.

Until a few years ago, relatively little attention was paid to the role of carbohydrates in dairy feeding other than that structural carbohydrates in roughages acted 


\section{S. TAMMINGA ET AL.}

as a source of fibre with important stabilizing properties for rumen fermentation and that carbohydrates in roughages and concentrates were an important energy yielding part of the diet. De Visser et al. (1980) were among the first to report differences in ruminal behaviour between non-structural carbohydrates like starch and sugars and structural carbohydrates like (crude) fibre in dairy concentrates. In a recent review Nocek \& Russell (1988) also emphasized the importance of differences between carbohydrate sources as a substrate for microbial synthesis. Structural carbohydrates in roughages are usually in a long form and give as such tectile stimuli to induce rumination, salivation and rumen motility and thus influence the conditions in the rumen (buffering capacity, pH, VFA-concentration). In the Netherlands the extent of the stimulus that is expected from a feed is compared with the assumed stimulus of long hay. These (relative) 'structural' values vary from 0 (ground forages and concentrates) to 1.2 (long straw). Based on these structural values it is now recommended that dairy diets have a structural value of at least 0.35 .

However, the conditions in the rumen are not only influenced by the structural value of the diet, but also depend on other factors, like the rate and extent of VFA production e.g. the rate and extent of carbohydrate degradation. Thus, structural carbohydrates in ground concentrates probably also play an important positive role in the stabilization of rumen fermentation, whereas large amounts of non-structural carbohydrates sometimes have a negative influence. The exact physico-chemical structure of the structural carbohydrates has not yet completely been established, but it is beyond doubt that their encrustration with lignin and/or cutin is of great importance for their digestive behaviour in the rumen.

Not only structural carbohydrates differ in behaviour in the rumen, large differences were also observed between non-structural carbohydrates, particularly with regard to the rate of ruminal degradation (Malestein et al., 1988; Tamminga et al., 1989b). When large amounts of starch and sugars were included in concentrates fed to dairy cows, ruminal $\mathrm{pH}$ could be dramatically reduced with a concomitant equally. dramatic rise in the levels of propionic and sometimes lactic acid in rumen fluid (de Visser et al., 1980). This led to the recommendation not to include more than $25 \%$ starch and sugars in concentrates fed to dairy cows. Soluble sugars were demonstrated to be an important contributor to the drop in $\mathrm{pH}$ but did not give the full explanation (Malestein \& van 't Klooster, 1986); differences in ruminal behaviour between starches of different origin were also contributing (Malestein \& van 't Klooster, 1986; Tamminga et al., 1989b). Further research showed that the negative influence of non-structural carbohydrates on rumen fermentation is largely caused by easily degradable carbohydrates such as soluble sugars, and rapidly degraded starches (Tamminga, unpublished results).

Although the exact mechanism has yet to be elucidated, it is beyond doubt that feeding starches, particularly less rapidly degradable starches, has an influence on milk composition. It reduces milk fat but enhances milk protein percentage (de Visser et al., 1990).

Proteins in ruminant feeds play two important roles. Firstly they provide the rumen microbes with $\mathrm{N}$, required for their growth and microbial protein synthesis in the rumen, an important source of amino acids for the ruminant animal. In addi- 
tion, feed proteins may be a significant source of animo acids themselves, because a varying part of feed proteins escape degradation in the rumen and become available for digestion in the small intestine.

Increasing levels of milk production require increasing amounts of concentrates in the diet. Different ingredients in such concentrate mixtures may have different properties leading to different profiles of absorbed nutrients and hence there is a growing interest in concentrate composition. For that reason, research was started to elucidate the characteristics of concentrate ingredients in terms of ruminal behaviour. The aim of this research was to get data which can be used to manipulate concentrate composition in such a way that combined with forages of different qualities optimum dairy diets can be composed under different physiological conditions.

\section{Materials and methods}

\section{Incubation procedures}

Three experiments were carried out with 4,3 and 4 lactating dairy cows, respectively, in which rumen degradation characteristics of cell wall components (NDF), starches and crude protein were determined by means of nylon bag incubations. In all experiments, dairy cows previously equipped with a large rumen cannula with an internal diameter of $10 \mathrm{~cm}$ (Bar Diamond Inc., Parma, Idaho, USA) were kept in a tie stall and fed twice daily with two equal portions of a diet consisting of 6 to $7 \mathrm{~kg}$ of long meadow hay and 12 to $14 \mathrm{~kg}$ of ground and pelleted commercial concentrates.

Rumen incubations to determine degradation characteristics of cell walls (Neutral Detergent Fibre) were with $0.5 \mathrm{~g}$ material in small bags $(45 \times 46 \mathrm{~mm})$, according to the method described by Robinson et al. (1986) with incubation times of $0,3,6,12$, 24,48 and 336 hours. Incubation of concentrate ingredients to determine the degradative behaviour of starch and crude protein in the rumen was with $5 \mathrm{~g}$ material in large nylon bags $(10 \times 17 \mathrm{~cm})$ as described earlier (Tamminga et al., 1990) with incubation times of $0,1,2,4,6,8$, and 12 hours for starch and $0,2.5,5.0,7.5$, $16.5,24,48$ and 336 hours for crude protein. After incubation the bags containing the residues were washed in a domestic washing machine for 1 hour without spinning and subsequently dried overnight at $70^{\circ} \mathrm{C}$.

\section{Analytical procedures}

Neutral Detergent Fibre (NDF) content in feeds was determined according to the method of Goering \& van Soest (1970), in residues after incubation according to the procedure described by Robinson et al. (1986) with some minor modifications. After extraction with Neutral Detergent and drying, the residue was ashed in a furnace at $550{ }^{\circ} \mathrm{C}$ to estimate $\mathrm{NDF}$ rather than NDR. Starch in the feeds and nylon bag residues after rumen incubation was measured enzymatically (Boehringer, Mannheim) with $\alpha$-amyloglucosidase on an auto-analyser (Breda Scientific, Breda, Netherlands) after the removal of soluble sugars by extraction with $40 \%$ ethanol 
followed by autoclaving at $128{ }^{\circ} \mathrm{C}$ for 120 minutes. Nitrogen $(\mathrm{N})$ in feeds and nylon bag residues was determined by the Dumas method (Merz, 1979).

\section{Treatment of results}

From the nylon bag incubation studies it became apparent that part of the starch and the crude protein could be washed out of the bags without incubation in the rumen. This proportion (S) was considered to be degraded instantaneously and completely. Part of the cell walls and crude protein did not disappear from the bags, not even after prolonged rumen incubations of 336 hours. This proportion (U) was considered to be undegradable. The remaining proportion was termed $B$ and can be calculated as 100-S-U. Results of nylon bag incubations were therefore fitted though iterative procedures by the following mathematical equations:

Crude protein:

$$
Y(t)=U+(100-S-U) \times e^{-k_{d} t}
$$

Cell walls (NDF): $\quad \mathrm{Y}(\mathrm{t})=\mathrm{U}+(100-\mathrm{U}) \times \mathrm{e}^{-\mathrm{k}_{\mathrm{d}}(\mathrm{t}-\mathrm{L})}$

Starch:

$$
Y(t)=(100-S) \times e^{-k_{d}}
$$

where:

$\mathrm{Y}(\mathrm{t})=$ residue at time $=\mathrm{t}$

$\mathrm{S}=$ fraction which can be washed out of nylon bags without rumen incubation

$\mathrm{U}=$ residue after 336 hours of incubation

$\mathrm{k}_{\mathrm{d}} \quad=$ degradation rate constant $\left(\mathrm{h}^{-1}\right)$

$\mathrm{L}=$ lag phase in hours, with a maximum of 10 hours

\section{Further calculations}

Rumen degradation characteristics as collected in this study can provide information which can be used to compose concentrates or diets, which will give an optimum rumen fermentation. As a first approach rumen available carbohydrates and rumen available crude protein were matched. Rumen availability (FNDF, FSST) was estimated from the total amount of NDF, starch or protein present in a feedstuff, corrected for the undegradable fraction (U) and for passage during the lag phase (L). Rumen availability was then estimated as the corrected amount present when degradation starts, multiplied by the ratio between rate of degradation $\left(\mathrm{k}_{\mathrm{d}}\right)$ and rate of passage $\left(\mathrm{k}_{\mathrm{p}}\right)$, assuming passage rates of $2.5 \%$ per hour for cell walls (Tamminga et al., 1989a) and 6\% per hour for protein and starch (Verité et al., 1987).

\section{Results}

Results on ruminal degradation of cell walls in concentrate ingredients are shown in Table 1 . Based on the best fit of the data to the model, two groups of ingredients 
Table 1. Rumen degradation characteristics of cell walls (NDF) in concentrate ingredients.

\begin{tabular}{|c|c|c|c|c|c|c|}
\hline Feedstuff & $\begin{array}{l}\text { NDF/DM } \\
\left(\mathrm{g} \mathrm{kg-1}^{-1}\right)\end{array}$ & $\begin{array}{l}U \\
(\%)\end{array}$ & $\begin{array}{l}\mathrm{L} \\
\text { (h) }\end{array}$ & $\begin{array}{l}\mathrm{k}_{\mathrm{d}} \\
\left(\% 0 \mathrm{~h}^{-1}\right)\end{array}$ & $\begin{array}{l}S+D \\
(g k g-1 D M)\end{array}$ & $\begin{array}{l}\text { FNDF } \\
\left(\mathrm{g} \mathrm{kg}^{-1} \mathrm{DM}\right)\end{array}$ \\
\hline Babassumeal & 655.0 & 40.6 & 5.4 & 7.7 & 389.1 & 256.6 \\
\hline Barley & 220.0 & $(27.0)$ & $(0.2)$ & (14.5) & 160.6 & 136.3 \\
\hline Beans & 178.0 & $(20.0)$ & $(4.0)$ & $(15.0)$ & 142.4 & 110.4 \\
\hline Beetpulp & 462.0 & 8.8 & 2.6 & 6.4 & 421.6 & 284.1 \\
\hline Brewers grains & 631.0 & 26.0 & 0.8 & 7.2 & 466.9 & 339.1 \\
\hline Coconutmeal & 563.0 & 18.1 & 3.0 & 7.2 & 461.1 & 317.5 \\
\hline Corn & 122.0 & $(10.0)$ & $(3.8)$ & $(5.1)$ & 109.8 & 67.0 \\
\hline Cornglutenfeed & 349.0 & 14.2 & 0.0 & 6.5 & 299.4 & 216.3 \\
\hline Cottonseedmeal & 270.0 & 33.9 & 8.7 & 6.5 & 178.5 & 103.7 \\
\hline Groundnutmeal & 125.0 & 30.4 & 0.0 & 11.7 & 87.0 & 71.7 \\
\hline Hominy feed & 282.5 & 6.4 & 0.0 & 16.3 & 264.4 & 229.3 \\
\hline Linseedmeal & 305.0 & 32.6 & 0.0 & 12.8 & 205.6 & 172.0 \\
\hline Lupins & 334.0 & 3.2 & 2.5 & 8.5 & 323.3 & 234.7 \\
\hline Macoyameal & 460.0 & 49.8 & 9.0 & 5.0 & 230.9 & 122.9 \\
\hline Milo & 131.0 & $(20.0)$ & $(0.0)$ & $(4.5)$ & 104.8 & 67.4 \\
\hline Millet & 164.0 & $(25.0)$ & $(0.0)$ & $(4.5)$ & 123.0 & 79.1 \\
\hline Nigerseedmeal & 374.0 & 54.1 & 0.0 & 38.6 & 171.7 & 161.2 \\
\hline Oats & 301.0 & $(27.0)$ & $(0.0)$ & $(4.5)$ & 219.7 & 141.3 \\
\hline Palmkernels & 342.0 & 52.5 & 10.0 & 4.5 & 162.5 & 81.1 \\
\hline Palmkerneloilmeal & 692.0 & 33.0 & 6.9 & 6.5 & 463.6 & 281.8 \\
\hline Peas & 175.0 & $(20.0)$ & $(4.0)$ & $(15.0)$ & 140.0 & 108.6 \\
\hline Potato & 89.0 & $(10.0)$ & $(0,0)$ & $(10.0)$ & 80.1 & 64.1 \\
\hline Rapeseedmeal & 286.0 & 30.4 & 0.0 & 16.6 & 199.1 & 173.0 \\
\hline Rice & 40.0 & $(40.0)$ & $(1.8)$ & $(4.5)$ & 24.0 & 14.7 \\
\hline Ricebran & 197.0 & 73.2 & 0.0 & 4.8 & 52.8 & 34.7 \\
\hline Sunflowerseedmeal & 394.0 & 53.1 & 0.0 & 8.2 & 184.8 & 141.6 \\
\hline Tapioca & 80.0 & $(27.0)$ & $(0,0)$ & $(5.0)$ & 58.4 & 38.9 \\
\hline Wheat & 135.5 & $(30.0)$ & $(0.0)$ & $(15.0)$ & 94.9 & 81.3 \\
\hline Wheat flour & 22.0 & $(30.0)$ & $(0.0)$ & $(12.5)$ & 15.4 & 12.8 \\
\hline Wheat shorts & 114.0 & $(30.0)$ & $(0.0)$ & $(10.0)$ & 79.8 & 63.8 \\
\hline Wheat middlings & 399.0 & 39.7 & 0.0 & 9.4 & 240.6 & 190.1 \\
\hline Wheat bran & 543.0 & $(30.0)$ & $(0.0)$ & $(7.7)$ & 380.1 & 286.9 \\
\hline
\end{tabular}

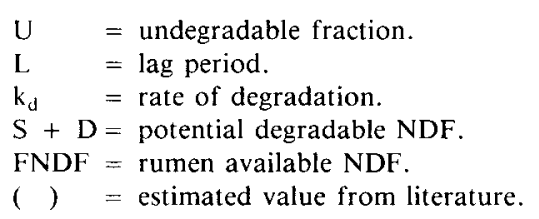

became apparent. One group in which degradation was best described by a model which has included a distinct lag phase, and one group for which the model does not include a distinct lag phase. The undegradable fraction $(U)$ varied from less than $10 \%$ (hominy feed, beet pulp, lupins) to over $50 \%$ (macoyameal, nigerseedmeal, sunflowerseedmeal). Rate of degradation $\left(\mathrm{k}_{\mathrm{d}}\right)$ varied from less than $5 \%$ per hour (macoyameal, palmkernels, ricebran) to almost $15 \%$ (hominyfeed, rapeseedmeal). These results correspond with those reported by Varga \& Hoover (1986). Nigerseedmeal behaved exceptionally with over $50 \%$ not available for ruminal degradation 
Table 2. Rumen degradation characteristics of starch plus sugars (SST) in concentrate ingredients.

\begin{tabular}{|c|c|c|c|c|c|}
\hline Feedstuff & $\begin{array}{l}\text { SST } \\
\left(\mathrm{g} \mathrm{kg}^{-1}\right)\end{array}$ & $\begin{array}{l}S \\
(\%)\end{array}$ & $\begin{array}{l}k_{d} \\
(\% 0 h-1)\end{array}$ & $\begin{array}{l}S+D \\
\left(g_{k g}^{-1} D M\right)\end{array}$ & $\begin{array}{l}\text { FSST } \\
\left(\mathrm{g} \mathrm{kg}^{-1} \mathrm{DM}\right)\end{array}$ \\
\hline Babassumeal & 42.0 & 84.5 & $(12.5)$ & 6.5 & 4.4 \\
\hline Barley & 604.0 & 64.5 & 24.2 & 214.4 & 171.8 \\
\hline Beans & 416.5 & 40.5 & 10.6 & 247.8 & 158.2 \\
\hline Beetpulp & 147.0 & 89.8 & $(12.5)$ & 15.0 & 10.1 \\
\hline Brewers grains & 63.0 & 39.7 & (12.5) & 38.0 & 25.7 \\
\hline Coconutmeal & 113.2 & 90.1 & $(12.5)$ & 11.2 & 7.6 \\
\hline Corn & 735.5 & 27.6 & 4.0 & 532.5 & 211.4 \\
\hline Cornglutenfeed & 324.3 & 62.0 & 10.2 & 123.2 & 77.6 \\
\hline Cottonseedmeal & 60.0 & 78.3 & $(12.5)$ & 13.0 & 8.8 \\
\hline Groundnutmeal & 157.0 & 65.0 & $(12.5)$ & 55.0 & 37.1 \\
\hline Hominyfeed & 495.0 & 33.9 & 5.3 & 327.2 & 152.7 \\
\hline Linseedmeal & 69.0 & 60.1 & $(12.5)$ & 27.5 & 18.6 \\
\hline Lupins & 67.0 & 91.0 & (12.5) & 6.0 & 4.1 \\
\hline Macoyameal & 162.0 & 89.9 & 25.4 & 16.4 & 13.2 \\
\hline Milo & 740.0 & 32.6 & 3.6 & 498.8 & 187.0 \\
\hline Millet & 664.0 & 41.6 & 8.3 & 387.8 & 225.1 \\
\hline Niegerseedmeal & 56.0 & 85.7 & $(12.5)$ & 8.0 & 5.4 \\
\hline Oats & 473.0 & 96.1 & 18.8 & 18.4 & 14.0 \\
\hline Palmkernels & 20.5 & 80.5 & $(12.5)$ & 4.0 & 2.7 \\
\hline Palmkerneloilmeal & 35.0 & 57.1 & $(12.5)$ & 15.0 & 10.1 \\
\hline Peas & 505.0 & 42.9 & 10.5 & 288.4 & 183.5 \\
\hline Potato & 781.0 & 33.9 & 4.9 & 516.2 & 232.1 \\
\hline Rapeseedmeal & 125.0 & 89.2 & $(12.5)$ & 13.5 & 9.1 \\
\hline Rice & 865.0 & 26.0 & 7.6 & 640.1 & 357.7 \\
\hline Ricebran & 331.5 & 27.8 & 11.8 & 239.3 & 158.6 \\
\hline Sunflowerseedmeal & 71.0 & 81.7 & $(12.5)$ & 13.0 & 8.8 \\
\hline Tapioca & 786.0 & 75.7 & 11.8 & 191.0 & 126.6 \\
\hline Wheat & 687.5 & 69.1 & 18.2 & 212.4 & 159.7 \\
\hline Wheat flour & 830.0 & 87.2 & 19.8 & 106.2 & 81.5 \\
\hline Wheat Shorts & 575.0 & 86.6 & 15.7 & 77.1 & 55.7 \\
\hline Wheat middlings & 287.4 & 88.5 & 24.2 & 33.1 & 26.5 \\
\hline Wheat bran & 191.0 & 87.0 & 20.8 & 24.8 & 19.3 \\
\hline
\end{tabular}

SST $=$ starch plus sugars.

$\mathrm{S} \quad=$ soluble fraction.

$k_{\mathrm{d}} \quad=$ rate of degradation.

$\mathrm{S}+\mathrm{D}=$ potential degradable insoluble starch.

FSST $=$ rumen available insoluble starch.

( ) = estimated value.

and a rate of degradation of the rumen available part of $38.6 \%$ per hour. Length of the lag phase was usually between 0 and 4 hours. Exceptions were cottonseedmeal, macoyameal, palmkernels and palmkerneloilmeal, showing lag periods of up to 10 hours. Regression analysis revealed no significant relationships between cell wall content and fraction $U$, rate of degradation or length of the lag phase. This finding also agrees with the results of Varga \& Hoover (1986).

Ruminal degradation characteristics of starches of different origin are shown in Table 2. The washed out fraction (S) varied from less than $30 \%$ (corn, rice, 
Table 3. Rumen degradation characteristics of crude protein $(\mathrm{N} \times 6.25)$ in concentrate ingredients.

\begin{tabular}{|c|c|c|c|c|c|c|}
\hline Feedstuff & $\begin{array}{l}\text { CP/DM } \\
(g k g-1)\end{array}$ & $\begin{array}{l}S \\
(\%)\end{array}$ & $\begin{array}{l}\mathrm{U} \\
(\%)\end{array}$ & $\begin{array}{l}k_{d} \\
\left(\% h^{-1}\right)\end{array}$ & $\begin{array}{l}S+D \\
\left(g \mathrm{~kg}^{-1} \mathrm{DM}\right)\end{array}$ & $\begin{array}{l}\text { FN } \\
\left(\mathrm{g} \mathrm{kg}^{-1} \mathrm{DM}\right)\end{array}$ \\
\hline Babassumeal & 201.5 & 0.6 & 12.0 & 2.2 & 176.1 & 47.9 \\
\hline Barley & 112.5 & $(25.0)$ & $(5.0)$ & (12.5) & 78.8 & 53.2 \\
\hline Beans & 263.0 & 62.8 & 0.4 & 10.8 & 96.8 & 62.2 \\
\hline Beetpulp & 103.0 & 12.2 & 6.3 & 5.2 & 83.9 & 38.8 \\
\hline Brewers grains & 249.0 & 4.6 & 30.1 & 5.1 & 162.6 & 74.6 \\
\hline Coconutmeal & 215.2 & 16.6 & 3.4 & 2.9 & 172.2 & 56.4 \\
\hline Corn & 103.1 & $(15.0)$ & $(5.0)$ & (3.5) & 82.5 & 30.4 \\
\hline Cornglutenfeed & 201.8 & 44.9 & 5.5 & 5.2 & 100.1 & 46.2 \\
\hline Cottonseedmeal & 486.0 & 13.4 & 1.8 & 7.6 & 412.1 & 230.0 \\
\hline Groundnutmeal & 545.0 & 24.5 & 0.0 & 14.8 & 411.5 & 292.6 \\
\hline Hominyfeed & 141.5 & 27.9 & 1.7 & 7.8 & 99.6 & 56.4 \\
\hline Linseedmeal & 333.5 & 17.2 & 4.1 & 5.0 & 262.5 & 119.8 \\
\hline Lupins & 341.5 & 25.5 & 0.3 & 12.9 & 253.6 & 172.9 \\
\hline Macoyameal & 108.0 & 27.8 & 10.9 & 2.3 & 66.2 & 18.3 \\
\hline Milo & 125.0 & $(10.0)$ & $(10.0)$ & (3.5) & 100.0 & 36.8 \\
\hline Millet & 137.5 & $(15.0)$ & $(10.0)$ & $(5.0)$ & 103.1 & 46.9 \\
\hline Nigerseedmeal & 361.0 & 9.4 & 5.4 & 10.6 & 307.6 & 196.1 \\
\hline Oats & 125.0 & $(30.0)$ & $(5.0)$ & $(10.0)$ & 81.3 & 50.8 \\
\hline Palmkernels & 103.5 & 8.0 & 6.6 & 2.4 & 88.4 & 25.1 \\
\hline Palmkerneloilmeal & 151.0 & 8.8 & 6.8 & 3.5 & 127.4 & 46.6 \\
\hline Peas & 254.1 & 55.6 & 0.0 & 9.0 & 112.8 & 67.5 \\
\hline Potato & 93.8 & $(15.0)$ & $(5.0)$ & $(7.5)$ & 75.0 & 41.7 \\
\hline Rapeseedmeal & 369.0 & 21.2 & 5.9 & 13.8 & 269.0 & 187.6 \\
\hline Rice & 94.0 & $(15.0)$ & $(10.0)$ & $(5.0)$ & 70.5 & 32.0 \\
\hline Ricebran & 143.0 & 23.2 & 10.3 & 8.3 & 95.1 & 55.3 \\
\hline Sunflowerseedmeal & 371.5 & 14.7 & 3.4 & 14.7 & 304.4 & 216.1 \\
\hline Tapioca & 31.2 & $(25.0)$ & $(5.0)$ & $(5.0)$ & 21.8 & 9.9 \\
\hline Wheat & 137.5 & $(25.0)$ & $(6.0)$ & $(20.0)$ & 94.9 & 73.0 \\
\hline Wheat flour & 118.8 & $(25.0)$ & $(6.0)$ & $(17.5)$ & 82.0 & 61.0 \\
\hline Wheat shorts & 200.0 & (25.0) & $(6.0)$ & (17.5) & 138.0 & 102.8 \\
\hline Wheat middlings & 191.1 & 11.1 & 6.4 & 13.4 & 157.7 & 109.0 \\
\hline Wheat bran & 168.8 & $(25.0)$ & $(6.0)$ & $(15.0)$ & 116.5 & 83.2 \\
\hline
\end{tabular}

$\mathrm{U} \quad=$ undegradable fraction.

$\mathrm{S}=$ soluble fraction.

$\mathrm{k}_{\mathrm{d}} \quad=$ rate of degradation.

$\mathrm{S}+\mathrm{D}=$ potential degradable insoluble crude protein.

FN = available insoluble crude protein.

( ) = estimated value from literature.

ricebran) to over $90 \%$ (oats, lupins). Rate of degradation $\left(\mathrm{k}_{\mathrm{d}}\right)$ of insoluble starch varied from less than $5 \%$ (corn, milo, potato) to almost $25 \%$ per hour (barley, macoyameal, wheat middlings). No relationship was found between solubility and rate of degradation.

In Table 3 ruminal degradation characteristics are shown for crude protein in a variety of feedstuffs. Washed out fraction ranged between less than $5 \%$ (babassumeal, brewer's grains) and over $50 \%$ (beans, peas), the undegradable proportion between $0 \%$ (groundnutmeal, peas) and $30 \%$ (brewer's grains) and rate of degra- 


\section{S. TAMMINGA ET AL.}

Table 4. Ratio between total (FN), soluble ( $\mathrm{SN}$ ) and insoluble nitrogen (EN) and total (FCB), soluble (SCB) and insoluble (ECB) rumen available carbohydrates.

\begin{tabular}{|c|c|c|c|c|}
\hline Feedstuff & $\mathrm{n}$ & $\begin{array}{l}\mathrm{FN} / \mathrm{FCB} \\
\left(\mathrm{g} \mathrm{kg}^{-1}\right)\end{array}$ & $\begin{array}{l}\mathrm{SN} / \mathrm{SCB} \\
(\mathrm{g} \mathrm{kg}-1)\end{array}$ & $\begin{array}{l}\mathrm{EN} / \mathrm{ECB} \\
(\mathrm{g} \mathrm{kg}-1)\end{array}$ \\
\hline Babassumeal & 2 & 26.5 & 5.5 & 29.3 \\
\hline Barley & 1 & 18.7 & 11.6 & 27.6 \\
\hline Beans & 4 & 83.2 & 156.7 & 37.1 \\
\hline Beetpulp & 2 & 19.3 & 15.2 & 21.1 \\
\hline Brewers grains & 1 & 35.3 & 73.3 & 32.7 \\
\hline Coconutmeal & 5 & 34.5 & 56.0 & 27.7 \\
\hline Corn & 2 & 15.2 & 12.2 & 17.5 \\
\hline Cornglutenfeed & 3 & 44.2 & 72.1 & 25.2 \\
\hline Cottonseedmeal & 1 & 296.1 & 221.8 & 327.2 \\
\hline Groundnutmeal & 1 & 323.3 & 209.3 & 430.3 \\
\hline Hominyfeed & 2 & 27.9 & 37.6 & 23.6 \\
\hline Linseedmeal & 2 & 122.2 & 221.3 & 100.6 \\
\hline Lupins & 2 & 138.7 & 228.1 & 115.9 \\
\hline Macoyameal & 1 & 27.5 & 33.0 & 21.6 \\
\hline Milo & 1 & 15.9 & 8.3 & 23.2 \\
\hline Millet & 1 & 18.6 & 11.9 & 24.7 \\
\hline Nigerseedmeal & 1 & 171.5 & 113.1 & 188.3 \\
\hline Oats & 1 & 23.2 & 13.2 & 52.3 \\
\hline Palmkernels & 2 & 53.2 & 79.8 & 48.0 \\
\hline Palmkerneloilmeal & 2 & 30.7 & 106.4 & 25.5 \\
\hline Peas & 2 & 65.7 & 104.3 & 37.0 \\
\hline Potato & 1 & 15.9 & 8.5 & 22.5 \\
\hline Rapeseedmeal & 2 & 144.9 & 112.3 & 164.9 \\
\hline Rice & 1 & 12.4 & 10.0 & 13.8 \\
\hline Ricebran & 3 & 49.6 & 57.6 & 45.8 \\
\hline Sunflowerseedmeal & 1 & 207.7 & 150.1 & 229.9 \\
\hline Tapioca & 1 & 3.7 & 2.1 & 9.6 \\
\hline Wheat & 2 & 24.0 & 11.6 & 48.5 \\
\hline Wheat bran & 1 & 17.7 & 6.6 & 103.5 \\
\hline Wheat flour & 1 & 39.6 & 16.1 & 137.5 \\
\hline Wheat middlings & 2 & 44.2 & 13.3 & 80.5 \\
\hline Wheat shorts & 1 & 42.5 & 40.6 & 43.5 \\
\hline
\end{tabular}

$\mathrm{FN} / \mathrm{FCB}=$ ratio between total nitrogen and total carbohydrates.

$\mathrm{SN} / \mathrm{SCB}=$ ratio between soluble nitrogen and soluble carbohydrates.

$\mathrm{EN} / \mathrm{ECB}=$ ratio between insoluble nitrogen and insoluble carbohydrates.

$\mathrm{n}=$ number of batches.

dation between $2 \%$ (babassumeal, palmkernels) and almost $15 \%$ per hour (groundnutmeal, sunflowerseedmeal). No relationship was found between $\mathrm{S}$ and $\mathrm{k}_{\mathrm{d}}$ or between $\mathrm{U}$ and $\mathrm{k}_{\mathrm{d}}$.

From the rumen degradation characteristics as collected in these studies it was possible to estimate the proportion of protein or starch escaping degradation in the rumen. Rumen escape of starch appears to be very variable between grains (Tamminga et al., 1989b). High escape values were observed for corn and milo, low values for wheat and oats. Escape values for starch in by-product ingredients largely reflected those of the original seeds or tubers. Variation in rumen escape was equally 
dependant on $\mathrm{S}$ and $\mathrm{k}_{\mathrm{d}}$. These factors explained 67 and $68 \%$ of the total variation, respectively. Rumen escape values for crude protein were very variable (Tamminga \& Ketelaar, 1988). High values were observed for ingredients high in cell wall components, which could partly be explained by the high proportion which was resistant against degradation.

Results on the estimated ratio between rumen available crude protein and rumen available carbohydrates, expressed as $\mathrm{gN} \mathrm{kg}^{-1}$ carbohydrates are presented in $\mathrm{Ta}$ ble 4. Data for feed ingredients which were not investigated for one of the components were estimated from literature values. Rate of cell wall degradation and length of the lag time were calculated from Varga \& Crooker (1986) and McBurney et al. (1986), protein solubility values from Crooker et al. (1979) and Waldo \& Goering (1979), protein undegradability from ADIN (Khrishnamoorthy et al., 1982) and rate of protein degradation from de Boever et al. (1984). These estimates may not always be sufficiently accurate, but because the proportion of cell walls, insoluble starch or insoluble protein in the ingredients not investigated was usually of minor importance, this seems a reasonable approach. Balancing concentrates for an optimum rumen fermentation was refined further by comparing soluble protein and carbohydrates as well as insoluble but degradable protein and carbohydrates. The results are also shown in Table 4 .

\section{Discussion}

\section{Validation of degradation models}

Information as presented in this paper could be useful for ration formulation. The figures presented in Tables 1 to 3 can be regarded as a first attempt to set up a data base. To become succesful in this respect, a certain degree of standardisation will be required. This is as yet far from achieved. Various models to describe rumen degradation of feed components are possible. In the choice of variables used to describe the model, biological or mathematical considerations may prevail. The most widely used model is a first order kinetics equation. Methods used to solve such an equation include non-linear iterative least square regresssion, least square regression of logarithmic-transformed residuals with or without correction for an estimated or measured ruminally undegraded residue, and curve peeling. Alternatives are models with a more mathematical background, such as Gompertz curves (Sauvant et al., 1985). Although they may be more accurate in fitting the data (Sauvant et al., 1985), their biological interpretation is often difficult, reason why biologically orientated models are more popular.

In models used to describe the ruminal degradation of cell walls in a biological sense, the number of pools usually varies between 1 and 3 (Nocek \& English, 1986; Robinson et al., 1986). Rate of degradation may be assumed constant per pool (Nocek \& English, 1986; Robinson et al., 1986) or variable (Sauvant et al., 1985) and the model may or may not contain a discrete lag phase. Finally the mathematical procedure to describe the model may vary (Nocek \& English, 1986).

In a comparison of a number of biological models Robinson et al. (1986) showed 
that the degradation of cell walls can often be described quite adequately by a first order kinetics equation with two fractions, one degradable and one undegradable. They also showed that for some ingredients (e.g. babassumeal and brewers' grains) rumen degradation of structural carbohydrates could be described more accurately by assuming 3 discrete fractions, one rapidly degradable, one slowly degradable and one undegradable. The number of measuring points in the research reported in this paper was however too small to make such a distinction.

Rumen degradation of starches was described quite satisfactorily by assuming two fractions, one soluble fraction which can be washed out without rumen incubation and one insoluble fraction which is degraded exponentially.

Rumen availability is not only determined by (rate of) degradation. Rate of passage may be equally important. Little information is available on the variation in rate of passage of concentrate feeds.

In our approach a constant value for each feed component was used, but differences seem apparent particularly due to differences in level of feed intake (Eliman \& Orskov, 1984; Robinson et al., 1987). Other factors such as the specific gravity of the feed particles may also be important (Fox et al., 1988). In their carbohydrate/protein system these authors attribute a rumen passage value to concentrate ingredients depending on the relative feed weights. However more research in this area is needed.

\section{Characterization of dietary carbohydrates}

Polysaccharides can be divided in structural and non-structural carbohydrates. One important difference between both groups is that in non-structural carbohydrates glucose is the predominant monomer, whereas in structural carbohydrates other than cellulose, other monomers like xylose, arabinose, mannose, fructose and glucuronic acids are also important. A second important difference is that in nonstructural carbohydrates monomers are predominantly linked together with alpha-1, 4 glycosidic linkages, whereas in structural carbohydrates the beta-1,6 linkage is predominant. Due to their differences in characteristics, structural and nonstructural carbohydrates play a different role in ruminant nutrition.

At present, carbohydrates in concentrates for dairy cows are valued only on the basis of their capacity to yield net energy for the host animal. Other important aspects are their value as an energy yielding substrate for anaerobic rumen microbes and the effect they may have on rumen fermentation. Characteristics, which largely determine the value of a feedstuff as an energy yielding substrate for rumen microbes, are its rumen availability and its rate of degradation. The latter also influences the type of end products which will result from fermentation (Murphy et al., 1982).

Large differences were observed with regard to rumen availability between cellwall-rich feedstuffs. This means that the amount of energy which can be extracted by rumen microbes also differs between feedstuffs. Examples of poor energy yielding substrates are babassu-, macoya- and nigerseedmeal, palm kernels, sunflowerseedmeal and wheat middlings. Such feed ingredients not only yield comparatively 
little energy to the rumen microbes, they also contribute to the rumen fill and cause a high substitution rate when fed together with forages (Varga \& Hoover, 1985; Jarrige et al., 1986). For the majority of cell-wall-rich concentrate ingredients, the ruminal rate of degradation was between 5 and $15 \%$ per hour and therefore they have a ruminal fermentation pattern which does not vary to a great extent.

Non-structural carbohydrates play a different role in ruminant nutrition. Their potential rumen availability is believed to be complete. Actual degradation then depends on solubility and the ratio between rate of degradation and rate of passage. Contrary to structural carbohydrates, solubility of non-structural carbohydrates is often high, resulting in a high proportion being degraded very rapidly. In addition rate of degradation shows a wider variation than that of structural carbohydrates and ranges between 5 and $25 \%$ per hour. Rate of degradation of non-structural carbohydrates is important in various ways. First of all it determines the rate at which energy becomes available for microbial growth, often a limiting factor for microbial activity in the rumen, which in turn is believed to be important with regard to rumen capacity. Rate of degradation of non-structural carbohydrates also influences the fermentation pattern (Murphy et al., 1982), which in turn determines the amount of energy which is extracted (Tamminga, 1979) by the microbes. Because of their much wider range in degradation rates as compared to those of structural carbohydrates, rate of degradation of non-structural carbohydrates can be used as a means to match the availability of different nutrients for rumen microbes (Nocek \& Russel, 1988). This could be important in the utilisation of non-protein nitrogen and rumen degradable protein as source of $\mathrm{N}$ for microbial synthesis.

On the other hand different carbohydrate sources may interfere with each other. Large amounts of easily degradable non-structural carbohydrates may inhibit the degradation of structural carbohydrates, either directly as a competitive substrate or indirectly through causing a reduced $\mathrm{pH}$ (Hoover, 1986).

Finally the proportion of carbohydrates escaping degradation in the rumen is to a large extent dependant on rate of degradation. Escape of structural carbohydrates is undesirable, because the rumen is by far the most important compartment where structural carbohydrates can be degraded. For the host animal structural carbohydrates, which are not degraded in the rumen, are largely bulk, which has to be cleared from the intestinal tract at the expense of sloughing of intestinal cells, giving rise to the loss of considerable amounts of endogenous protein (NRC, 1989).

Escape from rumen degradation of non-structural carbohydrates may be benificial, because they can be digested in the small intestine. This usually results in a reduced milk fat content and a somewhat enhanced milk protein content. The reasons why that happens are not entirely understood yet.

\section{Optimizing ration composition}

Feed evaluation in domesticated animals is at present on the basis of energy and protein. Yet for maintenance as well as (re)production domestic animals need nutrients such as glucose, amino acids and fatty acids. New approaches on feed evaluation recognize this (McRae et al., 1988) and attempts were already made to take such ap- 


\section{S. TAMMINGA ET AL.}

proaches into account (Webster et al., 1988; Fox et al., 1988). In ruminant nutrition the amount and nature of nutrients is very much influenced by rumen fermentation (Tamminga \& van Vuuren, 1988). Ensuring optimum rumen fermentation cannot be achieved on the basis of feed evaluation systems presently in use. For that purpose data as presented in the Tables 1 to 3 in this report seem more appropriate. To achieve optimum microbial growth yields the ratio of rumen available nitrogen (FN) to rumen available carbohydrate (FCB) should be around $25 \mathrm{~g}$ nitrogen per $\mathrm{kg}$ available carbohydrates (Czerkawski, 1986), based on the assumption that the organic matter truly fermented in the rumen almost entirely consists of carbohydrates. Variation in total nitrogen to total carbohydrates available (FN/FCB in Table 4) varies between 4 (tapioca) and 293 (cottonseedmeal). Hence based on these results, it is possible to optimize rumen fermentation. However the moment at which $\mathrm{N}$ and carbohydrates become available may not coincide. A further refinement is then possible by matching not only FN/FCB, but to do this for the soluble (SN/SCB) and insoluble (EN/ECB) fractions separately. As can be seen from Table 4 variation in the $\mathrm{N}$ to carbohydrate ratio in soluble and insoluble fractions is between 5 (babassumeal) and 228 (lupins) and between 10 (tapioca) and 430 (groundnutmeal), respectively.

The next step in optimizing rumen fermentation should be the inclusion of the roughage part of the diet. Therefore simular rumen degradation characteristics should be determined for forages, which in the future will make it possible to optimize rumen fermentation of the whole diet. In optimizing rumen fermentation too large amounts of soluble or rapidly degradable carbohydrates should be avoided, because they may give rise to an excessive VFA production resulting in a low $\mathrm{pH}$, which will slow down the degradation of structural carbohydrates. Also too large amounts of soluble or rapidly degradable protein should be avoided, because they may result in excessive $\mathrm{NH}_{3}$ production followed by urea excretion.

\section{Conclusions}

Date presented and the approach outlined in this paper are a first attempt for the construction of a data base of rumen characteristics of feeds for ruminants. Before sufficient information is available to build reliable and robust prediction models, much more information has to be collected in the near future. Especially information is needed on the variation between different batches of the same concentrate ingredient. Also information on rumen characteristics of forages differing in species, origin, age, level of fertilisation, season, way of harvesting, and so on, is required.

\section{References}

Boever, J. L. de, J. V. Aerts, B. G. Cottyn, J. M. Vanacker \& F. X. Buysse, 1984. The in sacco protein degradability vs. protein solubility of concentrate ingredients. Zeitschrifte für Tierphysiologie Tierernährung und Futtermittelkunde 52:227-234.

Crooker, B. A., C. J. Sniffen, W. H. Hoover \& L. L. Johnson, 1978. Solvents for soluble nitrogen measurements in feedstuffs. Journal of Dairy Science 61:437-447. 
Czerkawski, J. W., 1986. An introduction to rumen studies. Pergamon Press, Oxford, England, 236 pp.

Eliman, M. E. \& E. R. Orskov, 1984. Factors affecting the outflow of protein supplements from the rumen. 1. Feeding level. Animal Production 38:45-51.

Englyst, H., 1989. Classification and measurement of plant polysaccharides. Animal Feed Science and Technology 23:27-42.

Fox, D. G., C. J. Sniffen, J. D. O'Connor, J. B. Russel \& P. J. van Soest, 1988. The Cornell net carbohydrate and protein system for evaluating cattle diets. Cornell University Agricultural Experiment Station Bulletin, Ithaca, NY, USA, $67 \mathrm{pp}$.

French, D., 1973. Chemical and physical properties of starch. Journal of Animal Science 37:1048-1061.

Goering, H. K. \& P. J. van Soest, 1970. Forage fiber analysis. Agricultural Handbook No. 379, ARC, USDA, Washington. pp. 1-12.

Hoover, W. H., 1986. Chemical factors involved in ruminal fiber digestion. Journal of Dairy Science 69:2755-2766.

Jarrige, R., C. Demarquilly, J. P. Dulphy, A. Hoden, J. Robelin, C. Beranger, Y. Geay, M. Journet, C. Malterre, D. Micol \& M. Petit, 1986. The INRA 'Fill Unit' system for predicting the voluntary intake of forage-based diets in ruminants. A review. Journal of Animal Science 63:1737-1758.

Khrishnamoorthy, U., T. V. Muscato, C. J. Sniffen \& P. J. van Soest, 1982. Nitrogen fractions in selected feedstuffs. Journal of Dairy Science 65:217-225.

Malestein, A. \& A. Th. van 't Klooster, 1986. Influence of ingredient composition of concentrates on rumen fermentation rate in vitro and in vivo and on roughage intake of dairy cows. Journal of Animal Physiology and Animal Nutrition 55:1-13.

Malestein, A., A. Th. van 't Klooster \& J. W. Cone, 1988. Degradability of various types of starch by incubation with rumen fluid or with bacterial $\alpha$-amylases. Journal of Animal Physiology and Animal Nutrition 59:225-232.

McBurney, M. I., M. S. Allen \& P. J. van Soest, 1986. Praseodynium and copper cation-exchange capacities of neutral-detergent fibres relative to composition and fermentation kinetics. Journal of the Science of Food and Agriculture 37:666-672.

McRae, J. C., P. J. Buttery \& D. E. Beever, 1988. Nutrient interactions in the dairy cow. In: P. C. Gransworthy (Ed.), Nutrition and lactation in the dairy cow. Butterworth, London, England, p. 55-75.

Merz, E., 1979. Neuer Automat zur Stickstoff Schnellbestimmung. G. I. T. Fachzeitung Lab. $14: 617-619$.

Murphy, M. R., R. L. Baldwin \& L. J. Koong, 1982. Estimation of stoichiometric parameters for rumen fermentation of roughage and concentrate diets. Journal of Animal Science 55:411-421.

Nocek, J. E. \& J. E. English, 1986. In situ degradation kinetics: Evaluation of rate determination procedures. Journal of Dairy Science 69:77-87.

Nocek, J. E. \& J. B. Russell, 1988. Protein and energy as an integrated system. Relationship of ruminal protein and carbohydrate availability to microbial synthesis and milk production. Journal of Dairy Science 71:2070-2107.

NRC, 1989. Nutrient requirements of dairy cattle. National Research Council, Washington, USA, 157 pp.

Robinson, P. H., J. G. Fadel \& S. Tamminga, 1986. Evaluation of mathematical models to describe neutral detergent residue in terms of its susceptibility to degradation in the rumen. Animal Feed Science and Technology 15:249-271.

Robinson, P. H., S. Tamminga \& A. M. van Vuuren, 1987. Influence of declining level of feed intake and varying proportion of starch in the concentrate on rumen ingesta quantity, composition and kinetics of ingesta turnover in dairy cows. Livestock Production Science 17:37-62.

Rooney, L. W. \& R. L. Pflugfelder, 1986. Factors affecting starch digestibility with special emphasis on sorghum and corn. Journal of Animal Science 63:1607-1623.

Sauvant, D., D. Bettrand \& S. Giger, 1985. Variations and precision of the in sacco dry matter digestion of concentrates and by-products. Animal Feed Science and Technology 13:7-23.

Sutton, J. D., 1985. Digestion and absorption of energy substrates in the lactating cow. Journal of Dairy Science 68:3376-3393.

Tamminga, S., 1979. Relation between different carbohydrates and microbial synthesis of protein. IVVO Report No. 130, $31 \mathrm{pp}$.

Tamminga, S. \& R. S. Ketelaar, 1988. Resistance against ruminal degradation of feeds for ruminants. 
(In Dutch.) IVVO Report No. 192, $37 \mathrm{pp.}$

Tamminga, S. \& A. M. van Vuuren, 1988. Formation and utilisation of end products of lignocellulose degradation in ruminants. Animal Feed Science and Technology 21:141-159.

Tamminga, S., P. H. Robinson, M. Vogt \& H. Boer, 1989a. Rumen ingesta kinetics of cell wall components in dairy cows. Animal Feed Science and Technology 25:89-98.

Tamminga, S., P. van der Togt, C. J. van der Koelen, C. Meliefste, M. Luttikhuis \& G. D. H. Claassen, 1989b. Ruminal behaviour of starches in dairy cows. (In Dutch.) Mededelingen IVVO, No. 14, 106 pp.

Tamminga, S., R. S. Ketelaar \& A. M. van Vuuren, 1990. Degradation of $\mathrm{N}$ in conserved forages in the rumen of dairy cows. Grass and Forage Science (in press).

Varga, G. A. and W. H. Hoover, 1983. Rate and extent of Neutral Detergent Fiber Degradation of feedstuffs in situ. Journal of Dairy Science 66:2109-2115.

Verité, R., B. Michalet-Doreau, P. Chapoutot, J. L. Peyread \& C. Poncet, 1987. Revision du système des proteines digestibles dans l'intestin (PDI). Bulletin Technique CRVZ 70:19-34.

Visser, H. de \& A. A. M, de Groot 1980. The influence of the starch and sugar content of concentrates on feed intake, rumen fluid, production and composition of milk. In: D. Giesecke, G. Dirksen \& M. Stangassinger (Eds), Metabolic disorders of farm animals. Institute for Physiology, Physiological Chemistry and Nutritional Physiology, University of Munich, Faculty of Veterinary Studies, pp. $41-48$.

Visser, H. de, P. L. van der Togt \& S. Tamminga, 1990. Structural and non-structural carbohydrates in concentrate supplements to silage based diets. 1. Feed intake and milk production. Netherlands Journal of Agricultural Science 38: 487-498.

Waldo, D. R. \& H. K. Goering, 1979. Insolubility of proteins in ruminant feeds by four methods. Journal of Animal Science 49:1560-1568.

Webster, A. J. F., R. D. Dewhurst \& C. J. Waters, 1988. Alternative approaches to the characterisation of feedstuffs for ruminants. In: W. Haresign \& D. J. A. Cole (Eds), Recent advances in animal nutrition, 1988, Butterworth, London, England, pp. 167-191.

Wohlt, J. E., C. E. Sniffen \& W. H. Hoover, 1973. Measurement of protein solubility in common feedstuffs. Journal of Dairy Science 56:1052-1057. 